\title{
Balancing Market Exploration and Market Exploitation in Product Innovation:
} A Contingency Perspective

\author{
Haisu Zhang, Ph.D. \\ School of Management \\ New Jersey Institute of Technology \\ University Heights \\ Newark, New Jersey 07102 \\ Phone: (973) 596-3248 \\ hzhangnpd@gmail.com
}

Fang Wu, Ph.D.

Naveen Jindal School of Management

University of Texas at Dallas

800 W. Campbell Road

Richardson, TX 75083

Phone: (972) 883-4740

fangwu@utdallas.edu

Anna Shaojie Cui, Ph.D.

College of Business Administration

University of Illinois at Chicago

601 S. Morgan Street

Chicago, IL 60607

Phone: (312) 996-7326

ascui@uic.edu 


\title{
Balancing Market Exploration and Market Exploitation in Product Innovation: A Contingency Perspective
}

\begin{abstract}
This paper examines three different ways to balance market exploration and market exploitation in product innovation. First, following the knowledge-based view, we examine whether market exploration and market exploitation have differential effects on various new product outcomes based on their different learning mechanisms. We find that market exploration facilitates new product innovativeness, whereas market exploitation is more beneficial for new product development speed. This indicates that market exploration and market exploitation influence new product financial performance via distinct paths. Second, we examine the interaction between market exploration and market exploitation on new product outcomes. Our findings indicate that the joint effects of market exploration and market exploitation reduce new product development speed and have no significant impact on new product innovativeness. Third, we examine the contingent role of customer need tacitness in influencing the effects of market exploration and market exploitation. Our results show that customer need tacitness strengthens the effects of market exploration on both new product innovativeness and new product development speed. In contrast, it weakens the effect of market exploitation on new product innovativeness, and has no significant influence on new product development speed. Our results provide specific guidelines for managers regarding how to achieve a balance between market exploration and market exploitation in product innovation.
\end{abstract}

Key Words: Market Exploration, Market Exploitation, Customer Need Tacitness, New Product Innovativeness, New Product Development Speed, New Product Financial Performance 


\section{Introduction}

In product innovation, firms are required to acquire and utilize market information efficiently and effectively in order to meet customer needs (e.g. Moorman, 1995; Slater \& Narver, 1995; Troy, Hirunyawipada, \& Paswan, 2008). Following the seminal work of March (1991), current literature has distinguished between two types of market learning activities in an organization: market exploration and market exploitation (e.g. Kim \& Atuahene-Gima, 2010; Kyriakopoulos \& Moorman, 2004). Market exploration refers to the search and pursuit of completely new knowledge and skills outside the firm's current product market, whereas market exploitation emphasizes the use and refinement of existing knowledge and skills in the current product market. Due to the distinction and tension between these two learning activities, recent studies have devoted to finding solutions for achieving organizational ambidexterity that allows a firm to simultaneously exploit existing competencies and explore new opportunities (e.g. Benner \& Tushman, 2003; Raisch et al., 2009). Despite the growing interests in this area of research, understanding organizational ambidexterity has proven to be a challenging task (e.g. Tushman \& O’Reilly, 1996; Raisch \& Birkinshaw, 2008), and there lacks consensus in the current literature on how to achieve this goal within and across organizations (e.g. Gupta, Smith, \& Shalley, 2006; Lavie, Kang, \& Rosenkopf, 2011).

This study aims to contribute to the existing literature by providing our perspective regarding how to balance market exploration and market exploitation in product innovation. Specifically, following the knowledge-based view and a contingency perspective, this study takes a closer look at the learning mechanisms underlying market exploration and market exploitation, and empirically examines three different ways to balance the two market learning activities in product innovation. Built upon previous literature on balancing exploration and 
exploitation within an organization (e.g. Levinthal \& March, 1993; Tushman \& O’Reilly, 1996; Raisch et al., 2009), our study aims to provide a comprehensive and unique view of achieving organizational ambidexterity by taking into account the differential effects of market exploration and market exploitation on distinct innovation outcomes as well as examining the contingent role of customer need tacitness in such learning processes. The objectives of this study are threefold:

First, following the knowledge-based view, we examine whether market exploration and market exploitation have differential effects on various new product outcomes based on their different learning mechanisms. Few existing studies have centered on whether exploration and exploitation will influence various new product outcomes differently with several exceptions (e.g. Atuahene-Gima, 2005; Kim \& Atuahene-Gima, 2010). Our study aims to contribute to the existing literature by comparing and contrasting the differential effects of market exploration and market exploitation on three distinct new product outcomes: new product innovativeness, new product development speed and new product financial performance. Further, this study goes beyond that by examining how the two types of market learning will influence new product financial performance via distinct paths.

Second, we directly model and test the ambidexterity hypothesis by examining the interaction effects of market exploration and market exploitation on new product outcomes. Empirical evidence is limited and inconsistent regarding the performance implications of such joint effects (e.g. Lavie, Kang, \& Rosenkopf, 2011; Raisch et al., 2009). Some research has lent support to the positive association between organizational ambidexterity and firm performance (e.g. He \& Wong, 2004; Katila \& Ahuja, 2002; Lubatkin et al., 2006), thereby indicating the complementarity of exploration and exploitation. Others have found a negative influence of such joint effects on performance outcomes (e.g. Atuahene-Gima, 2005; Atuahene-Gima \& Murray, 
2007; Nerkar, 2003). Our study attempts to provide new empirical evidence regarding the potential joint effects of these two market learning activities on innovation outcomes. Our findings indicate that the joint effects of market exploration and market exploitation reduce new product development speed, and have no significant impact on new product innovativeness. These findings provide new insights into how to achieve an optimal balance between market exploration and market exploitation in order to gain desirable innovation outcomes.

Third, we examine the contingent role of customer need tacitness and assess whether the effects of market exploration and market exploitation on innovation outcomes differ depending on the level of customer need tacitness. Understanding customer needs is not an easy task since such information can be tacit and hard to articulate (De Luca \& Atuahene-Gima, 2007; Madhavan \& Grover, 1998). The tacitness can affect whether specific information will be effectively harnessed and integrated into the new product development (NPD) process (De Luca \& Atuahene-Gima, 2007; McEvily \& Chakravarthy, 2002). Even though past studies have started to explore a few notable internal and external contingency factors, such as market orientation and environmental uncertainty, in these two learning activities (e.g. Atuahene-Gima, 2005; Kim \& Atuahene-Gima, 2010; Kyriakopoulos \& Moorman, 2004), they did not take into account the characteristics of customer knowledge involved in such learning. This study fills this research gap and examines whether the type of knowledge involved in market exploration and market exploitation can play a contingent role in influencing innovation outcomes. We propose that when customer needs are highly tacit, market exploration, rather than market exploitation, would be more beneficial for new product outcomes. Our findings support the above proposition and help to provide specific guidelines for managers regarding how to balance market exploration and market exploitation in product innovation. 


\section{Theoretical Background}

\subsection{The Market Learning Process}

According to Sinkula (1994), an organization's market learning process encompasses the acquisition, distribution, interpretation and storage of market information. Past research has shown that an organization's inherent orientation and its abilities to process market-related information can be considered as sources of competitive advantage (Day, 1994; Jaworski \& Kohli, 1993; Slater \& Narver, 1995). There is also ample empirical support that demonstrates that market information in organizational learning is crucial for NPD performance (e.g. Li \& Calantone, 1998; Rodríguez-Pinto, Carbonell, \& Rodríguez-Escudero, 2011) as well as firm performance (e.g. Cano, Carrillat, \& Jaramillo, 2004; Morgan, Vorhies, \& Mason, 2009).

Several related streams of research have examined the underlying mechanisms of market learning, including market orientation (Hurley \& Hult, 1998; Slater \& Narver, 1995) and information-processing view of an organization (Huber, 1991; Sinkula, 1994). The literature on market orientation emphasizes developing an organizational culture that gears towards "being market-oriented” (Hurley \& Hult, 1998; Slater \& Narver, 1995). It promotes developing an organizational mind-set that facilitates the generation, dissemination and responsiveness of market intelligence (Morgan, Vorhies, \& Mason, 2009), and proactively shapes the market demand when needed (Slater \& Narver, 1995). Another large body of research on market learning centers on the information-processing view of an organization (Huber, 1991; Sinkula, 1994). An organization is often engaged in finding ways to process market information efficiently and effectively in order to acquire, disseminate, and apply new market information and strive towards gaining sustainable competitive advantage in the long run (Day, 1994; Moorman, 1995). 
While these streams of research have helped to advance our understanding of the market learning process, few studies take into account the characteristics of market knowledge or the performance objectives of such learning. These two factors are important in assessing marketing learning for a firm since they can play a major role in the formation of a firm's marketing capabilities (De Luca \& Atuahene-Gima, 2007; Li \& Calantone, 1998), which could ultimately lead to better new product outcomes.

\subsection{Market Exploration and Market Exploitation}

Following the seminal work of March (1991) as well as several recent studies on market learning (e.g. Kim \& Atuahene-Gima, 2010; Kyriakopoulos \& Moorman, 2004), we distinguish between two types of market learning activities, market exploration and market exploitation. According to March (1991, p. 85), the essence of exploration is "experimentation with new alternatives" that has uncertain and distinct returns, whereas the essence of exploitation is "the refinement and extension of existing competences, technologies, and paradigms" whose return is positive and proximate. Applying March's view to the domain of market learning, we define market exploration as the search and pursuit of completely new knowledge and skills in the new and/or emergent market, whereas market exploitation refers to the use and refinement of existing knowledge and skills in the current market (Kim \& Atuahene-Gima, 2010; Kyriakopoulos \& Moorman, 2004).

Market exploration involves broad search beyond a firm's current product market. It aims at discovering new possibilities and creating new knowledge outside the firm's current market boundaries. In contrast, market exploitation emphasizes following existing organizational routines, and expanding and refining an organization's existing knowledge towards the current customer base (March, 1991; Kim \& Atuahene-Gima, 2010). Due to the 
differences in their learning mechanisms, these two types of market learning tend to compete for resources within an organization. Since exploiting existing knowledge tends to give immediate and predictable returns, a firm has a tendency to overly rely on exploiting its existing competencies which may lead to "competence traps" (Leonard-Barton, 1992; Levinthal \& March, 1993). In contrast, firms that engage predominantly in market exploration may find it difficult to gain the return of its newly discovered knowledge, thereby creating an endless cycle of "failure traps” (Gupta, Smith, \& Shalley, 2006; Levinthal \& March 1993).

Due to the inherent tension between market exploration and market exploitation, there is increasing attention in the literature to finding solutions to achieve an optimal balance between them which allows firms to develop both activities simultaneously for their long-term survival and growth (e.g. Benner \& Tushman, 2003; Raisch et al., 2009). Tushman and O’Reilly (1996) were the first to propose the idea of pursuing organizational ambidexterity which allows a firm to simultaneously develop exploration and exploitation in order to achieve superior performance. Recent studies have started to investigate various organizational configurations and contingency factors which may help to alleviate the tension between exploration and exploitation and realize the potential benefits of jointly pursuing these two activities within and across organizations (e.g. Lavie, Kang, \& Rosenkopf, 2011; Raisch et al., 2009).

Despite the growing interests in finding solutions to achieving organizational ambidexterity, this is in fact a daunting task (Zhou and Wu, 2010). The inconsistent findings in the literature call for more research to find the appropriate organizational configurations and contingency factors that would allow a firm to manage the tension between these two learning activities so as to realize the potential benefits of exploiting existing competence while exploring new opportunities at the same time (e.g. Lavie, Kang, \& Rosenkopf, 2011; Raisch et al., 2009). 


\subsection{Tacit vs. Explicit Customer Knowledge}

The knowledge-based view has suggested that an organization must create and maintain its own unique knowledge stock to achieve competitive advantage (Grant, 1996). One dimension of the knowledge creation process lies on the distinction between tacit knowledge and explicit knowledge involved in organizational learning (Nonaka, 1994; Nonaka \& Takeuchi, 1995). Tacit knowledge is often difficult to codify and communicate within and across firm boundaries. In contrast, explicit knowledge can be easily codified and transferred between organizational members. Since tacit knowledge is often embedded within an organization, it tends to create additional challenges for managing knowledge creation and integration (Grant, 1996; Nonaka, 1994). Research has demonstrated the validity of knowledge as a contingency factor in organizational studies (Birkinshaw, Nobel, \& Ridderstråle, 2002; De Luca \& AtuaheneGima, 2007).

We propose that the type of knowledge involved in market learning can play a contingent role in influencing the effects of market learning on new product outcomes. Even though understanding and satisfying customer needs is the center of market learning and a key driver for new product success, customers are often unable to explicitly articulate their needs or even can be unclear about their own needs. Extant literature has shown that this kind of tacit customer knowledge can undermine firms' abilities to obtain valuable information, and using measures to unveil such tacit information can help to overcome challenges in acquiring customer knowledge and thus facilitate innovation development (Ganesan, Malter, \& Rindfleisch, 2005; Madhavan \& Grover, 1998; Nonaka \& Takeuchi, 1995). As a result, this study focuses on examining the contingent role of customer need tacitness in product innovation. Examining this knowledgerelated contingent factor can help us to gain a better understanding of whether the effects of 
market exploration and market exploitation on new product outcomes differ depending on the level of customer need tacitness.

\section{Hypothesis Development}

We examine three new product outcomes in this study: new product innovativeness, new product development speed and new product financial performance. New product innovativeness refers to the degree of product newness (Moorman, 1995). It measures the extent to which the new product is novel to the industry and offers market and technological discontinuity compared with existing products (Moorman, 1995). New product development speed refers to the extent to which the NPD team follows its timeline in the overall development process (Carbonell \& Rodriguez, 2006). New product financial performance refers to the performance indicator of a new product relative to its stated objectives, including return on investment, profit margin, sales and market share (Moorman, 1995; Kyriakopoulos \& Moorman, 2004). New product innovativeness is generally considered as a product-based outcome while new product development speed as a process-based outcome. These two new product outcomes would ultimately influence the financial performance of a new product. Since market exploration and market exploitation involve different underlying learning mechanisms, these two learning activities may lead to different new product outcomes via their distinct paths. The conceptual model is presented in Figure 1.

[Figure 1 about here]

\subsection{Effects of Market Exploration and Market Exploitation on New Product Outcomes}

\subsubsection{New Product Innovativeness}

New product innovativeness requires the input of new knowledge beyond the firm’s existing learning trajectory. Due to its emphasis on experimentation and risk taking, market exploration allows firms to search for new or unrecognized customer needs, and identify novel 
solutions to meet those needs. As these solutions are often beyond current market experience, market exploration can facilitate the generation of unique product benefits not obtainable from previous products (Kim \& Atuahene-Gima, 2010). Furthermore, the exploration of new information can increase the firm's knowledge breadth with respect to its customers and product domains. It has been suggested that knowledge breadth can help to integrate various types of market intelligence, which could result in novel combinations of customer information (De Luca \& Atuahene-Gima, 2007; Kogut \& Zander, 1992). In addition, a broader knowledge base can increase a firm's absorptive capacity that would foster better integration and utilization of new knowledge to generate more innovative product solutions (Cohen \& Levinthal, 1990; Grant, 1996).

Although the exploitation of existing customer knowledge may also help to generate more innovations because it can increase a firm's knowledge depth (De Luca \& Atuahene-Gima, 2007; Rindfleisch \& Moorman, 2001), we argue that market exploration is more beneficial than market exploitation for new product innovativeness. First, mere exploitation of existing knowledge may turn the firm’s core capabilities into core “rigidities” (Leonard-Barton, 1992). That is, overreliance on a firm's existing knowledge inhibits product creativity due to its confined learning domain. Exploiting a firm's existing competence is more likely to result in incremental innovation rather than radical innovation (Atuahene-Gima, 2005).

Second, market exploration emphasizes broad search beyond the current product market, whereas market exploitation focuses primarily on local search within the existing market. Meeting the needs of new customers motivates the firms to develop products that utilize fundamentally different technological base and provide substantially new benefits (AtuaheneGima, 2005; Kyriakopoulos \& Moorman, 2004). On the other hand, to satisfy the needs of 
existing customers, firms often rely on product modifications and line extensions to improve current products (Atuahene-Gima, 2005; Kyriakopoulos \& Moorman, 2004). This would often result in incremental improvements of the existing products.

Third, the two types of market learning are closely associated with the firms' attitudes towards risks. During market exploration, firms are more willing to take on risks and thus could proactively resolve ambiguous customer problems to ensure the viability of innovative solutions. On the contrary, firms that are engaged in market exploitation tend to avoid taking risks by focusing on familiar customers and routines. In addition, developing radical innovation often requires a firm to take a higher level of risks due to the difficulty of incorporating and creating new product solutions beyond current knowledge trajectory, while producing incremental innovation is often more predictable and less risky due to its consistency with the existing knowledge base (Sorescu \& Spanjol, 2008). Therefore, compared to market exploitation, market exploration gives firms more opportunities to discover and develop highly innovative products.

H1: Market exploration has a stronger positive effect than market exploitation on new product innovativeness.

\subsubsection{New Product Development Speed}

We anticipate reverse effects of the two market learning activities on new product development speed, that is, market exploitation is more beneficial for new product development speed than market exploration. Different from new product innovativeness, new product development speed is considered as a process-based outcome in NPD. Market exploitation helps to improve process efficiency in the NPD process, thereby boosting the product development speed. First, market exploitation often relies on existing organizational routines to process market information. The familiarity and repetition of such a learning process can improve the speed and predictability of learning outcomes (Katila \& Ahuja, 2002). Second, market 
exploitation aims at utilizing a firm’s existing customer knowledge stock, which supports the development of common knowledge. The common knowledge facilitates communications among organizational members and is especially beneficial for improving the efficiency and effectiveness of cross-functional teams in NPD (Griffin \& Hauser, 1996). Third, the existing knowledge base, which is stored as part of the collective organizational memory, can serve as an effective conflict resolution tool among NPD team members and foster team consensus for efficient problem solving (Moorman \& Miner, 1997).

Although market exploration may also foster new product development speed and allow a firm to take advantage of most recent knowledge to improve process efficiency (Kim \& Atuahene-Gima, 2010; Katila \& Ahuja, 2002), we argue that the impact of market exploration on new product development speed is not as strong as that of market exploitation. First, market exploration is accompanied by broad search for new information. Firms often engage in additional information-processing activities, such as dissemination and interpretation of new information (Sinkula, 1994; Slater \& Narver, 1995), which require extra time to assimilate into their existing knowledge base (Kessler, Bierly, \& Gopalakrishnan, 2000). In contrast, market exploitation can take advantage of the information that is consistent with the firm's existing knowledge base. Such information is easier to use and more compatible with the existing NPD process (Kim \& Atuahene-Gima, 2010). Exploiting a firm’s existing knowledge base can help to speed up the NPD process and produce innovation that is less risky and more readily acceptable among existing customers (Rindfleisch \& Moorman, 2001).

Second, utilizing newly acquired information often requires fundamental changes in organizational behaviors and shifts in the mindsets of organizational members (Nonaka, 1994). This may require a firm to reconfigure its organizational resources and routines (e.g. Eisenhardt 
\& Martin, 2000; Zhou and Wu, 2010), which is often challenging due to organizational inertia (Adams, Day, \& Dougherty, 1998). Thus, the facilitating effect of market exploration on new product development speed may be difficult to realize.

Lastly, market exploitation employs existing methods to learn about customer needs, whereas market exploration allows firms to adopt experimental techniques. Existing methods are often standardized and thus requires less time to complete (March, 1991) while experimentation often requires a lot more iterations to find proper ways to collect and use market information (Thomke, 1998). Therefore, we expect:

H2: Market exploitation has a stronger positive effect than market exploration on new product development speed.

\subsubsection{New Product Financial Performance}

New product financial performance measures the degree to which an organization reaches its goals related to a new product's return on investment, profit margin, sales and market share compared to its stated objectives (Kyriakopoulos \& Moorman, 2004; Moorman, 1995). As stated above, while new product innovativeness can be considered as a product-based outcome and new product development speed as a process-based outcome, new product financial performance is viewed as the ultimate performance indicator of a new product.

Extant literature has provided ample theoretical and empirical support to the effects of new product innovativeness and new product development speed on the financial performance of a new product (e.g. Calantone, Harmancioglu, \& Droge, 2010; Henard \& Szymanski, 2001). A highly innovative product can provide customers with novel features that could better meet their needs and generate higher sales (Moorman, 1995) while a faster NPD process will bring the products to the market ahead of competitions (Rindfleisch \& Moorman, 2001). These two intermediate outcomes could ultimately contribute to higher new product financial performance 
overall. Combined with our rationales above regarding the effects of market exploration and market exploitation on new product innovativeness and new product development speed, we expect that the two market learning activities impact new product financial performance by improving the innovativeness of a new product and achieving a faster NPD process. As such, we hypothesize that:

H3: The effects of market exploration and market exploitation on new product financial performance are mediated by (a) new product innovativeness and (b) new product development speed.

\subsection{Joint Effects of Market Exploration and Market Exploitation on New Product Outcomes}

Despite the growing interests towards pursuing organizational ambidexterity within an organization, empirical evidence on the relationship between ambidexterity and performance remains inconsistent. Some research has provided support for the complementarity of exploration and exploitation on firm performance (e.g. He and Wong, 2004; Katila \& Ahuja, 2002; Lubatkin et al., 2006) while other studies have found a negative influence of the joint effects on performance outcomes (e.g. Atuahene-Gima, 2005; Atuahene-Gima \& Murray, 2007; Nerkar, 2003). Each firm needs to figure out its specific organizational configurations to manage the tension between these two learning activities.

We propose that whether the joint effects of market exploration and market exploitation have a complementary or substitution effect on product innovation depends on the performance objectives of the NPD process. When a firm's objective is to create highly innovative products, a high level of market exploration coupled with a high level of market exploitation may complement each other to jointly improve new product innovativeness. If the objective is to speed up the NPD process, a high level of market exploration may weaken the positive effect of market exploitation on process efficiency, thereby slowing down the NPD process. 
First, when a firm pursues market exploration that aims at discovering and acquiring new knowledge beyond current organizational boundaries, the newly acquired knowledge needs to be integrated with the existing knowledge base in order to create more novel knowledge combinations (Kogut \& Zander, 1992). Second, a higher level of existing competencies derived from market exploitation will increase a firm’s absorptive capacity (Cohen \& Levinthal, 1990). Meanwhile, through market exploration, a firm is able to detect changes in the environment and have the opportunity to reconfigure its activities to meet customers' changing demands. Under such a dynamic environment, a firm with a higher level of absorptive capacity can facilitate the reconfiguration process and create more innovative solutions (Eisenhardt \& Martin, 2000). Third, a higher level of exploitation may help a firm engaging in market exploration to get out of the "failure traps" by developing novel product solutions that could also have better market acceptance (He \& Wong, 2004; Katila \& Ahuja, 2002). As such, a higher level of market exploitation may strengthen the effect of market exploration on new product innovativeness. In contrast, when firms engage in a high level of market exploration and market exploitation simultaneously, it may reduce the efficiency in the NPD process, thereby decreasing new product development speed. First, even though both existing and new knowledge may potentially improve the efficiency of the NPD process, a firm that is engaged in high levels of both activities may have separate organizational units that specialize in each activity (Benner \& Tushman, 2003; Gupta, Smith, \& Shalley, 2006; Raisch et al., 2009). This kind of structural differentiation requires a firm to spend extra time to communicate between different organizational units and integrate the various information sources in the NPD process. Second, market exploration and market exploitation tend to create highly diverse information pool for the firm, the NPD process is likely to become lengthier because organizational members need more 
time to integrate completely new information with their existing knowledge base (Kessler, Bierly, \& Gopalakrishnan, 2000). Third, the diverse information source may also create more conflicts and disagreements among organizational members (Jehn, Northcraft, \& Neale, 1999). Thus, more time may be needed to resolve those conflicts and reach consensus to continue the NPD process. As such, we expect a high level of market exploration to weaken the effect of market exploitation on new product development speed. We hypothesize:

H4: The interaction between market exploration and market exploitation is (a) positively associated with new product innovativenesss, but (b) negatively associated with new product development speed.

\subsection{The Contingent Role of Customer Need Tacitness}

As noted by Nonaka (1994, p. 27), "many dimensions of customer needs take the form of tacit knowledge.” Even though tacit customer needs are difficult to express, codify, or document, understanding these needs is crucial for improving new product outcomes (De Luca \& AtuaheneGima, 2007; Nonaka \& Takeuchi, 1995). As such, we argue that the type of knowledge involved in the market learning process can play a contingent role in the relationships between the two market learning activities and the new product outcomes. That is, depending on the level of customer need tacitness, the effects of market exploration and market exploitation may differ due to their different learning mechanisms in the NPD process. In particular, we propose that when customer needs are highly tacit, market exploration, rather than market exploitation, can help to uncover the underlying needs of the customers, thereby contributing to higher new product innovativeness and new product development speed.

First, tacit knowledge is generally considered as immobile (Nonaka, 1994) or sticky information (von Hippel, 1994), as it is often difficult to transfer such knowledge from one individual to another. Tacit customer needs can be very difficult to capture because customers tend to be more aware of their current needs that can be well expressed (Leonard, 2007). In 
market exploration, firms are often engaged in proactively searching for new information beyond the current knowledge trajectory, which increases the chances of discovering customer needs that are hard to articulate. This process can motivate firms to develop novel solutions to meet such tacit needs (Atuahene-Gima, 2005). Furthermore, when customer needs are highly tacit, firms need to go through complex procedures to convert tacit knowledge into explicit information that can be more easily disseminated and utilized (Nonaka, 1994). This knowledge conversion process often requires adequate organizational flexibility to codify this difficult-to-verbalize information and support the incorporation of such knowledge into the NPD process (Nonaka \& Takeuchi, 1995). Market exploration is by nature a highly flexible learning activity (Thomke, 1998), which increases the possibility of uncovering tacit customer needs. It also helps to facilitate the discovery and development of novel solutions to address those needs. In addition, since tacit customer knowledge are often beyond the firm's understanding of its existing product markets, utilizing such information requires the firm to be more open to risks and uncertainties in the NPD process. Firms engaged in market exploration often have higher tolerance of risks and uncertainties, and thus are more likely to identify and utilize tacit customer knowledge in creating innovative product design.

When customer needs are highly tacit, market exploration can also help to shorten new product development speed. First, customer needs contain knowledge that can be used to accelerate the NPD process, such as know-how, skills, and customer visions (Kim \& AtuaheneGima, 2010; Katila \& Ahuja, 2002). A better understanding of their customer needs helps firms to define their target markets more clearly and thus reach the final product solutions faster (Kim \& Atuahene-Gima, 2010; Katila \& Ahuja, 2002). Firms can also use the knowledge to modify their technologies and development procedures (Levinthal \& March, 1993), which improves the 
efficiency of the NPD process. In addition, tacit customer needs are often unpredictable. Under such an uncertain situation, firms must be able to make quick judgments about whether and how to utilize tacit information effectively in the NPD process. Market exploration enables the firms to have a higher level of flexibility to reconfigure its organizational resources and processes quickly, thereby boosting new product development speed when customer needs are highly tacit (O’Reilly \& Tushman, 2008). Therefore, we expect that:

H5: Customer need tacitness strengthens the effects of market exploration on (a) new product innovativeness and (b) new product development speed.

We argue that a high level of customer need tacitness weakens the relationships between market exploitation and new product outcomes. First, market exploitation tends to focus on local search for new information (March, 1991), which makes it difficult to discover tacit customer needs. Those tacit needs may not be accessible to a firm due to the narrow scope of information search in market exploitation. Instead, market exploitation relies on the effective utilization of existing knowledge. Since tacit customer knowledge is often new to an organization, the existing knowledge base may not be useful to uncover and understand such information. Furthermore, market exploitation is often associated with established organizational routines, which may not give firms the flexibility to explore new ways of identifying and codifying tacit customer needs (Nonaka \& Takeuchi, 1995). As a result, when customer needs are highly tacit, firms engaged in market exploitation may find it difficult to incorporate such needs into developing innovative product solutions. Moreover, market exploitation does not promote risk taking, and often utilizes information that is consistent with existing market experience to reduce the uncertainties in the NPD process. Therefore, firms are less likely to utilize tacit customer needs to create novel innovation. 
Customer need tacitness may also weaken the role of market exploitation in improving new product development speed. First, since market exploitation relies on a firm’s existing knowledge base, the firm is often less willing to absorb tacit customer knowledge into product design or less able to deal with the complexity of such information. Firms may need to spend more time digesting tacit customer needs and encountering more failures in searching for the right product solutions. Second, market exploitation does not offer sufficient flexibility but rather emphasizes standardization in organizational processes (March, 1991). When customer needs are highly tacit, firms that rely primarily on market exploitation may find it difficult to adjust their standardized routines to accommodate the necessary design changes in order to better address those tacit needs (Leonard-Barton, 1992). This may lead to significant setbacks in the NPD process that would ultimately slow down the NPD process. In summary, we expect that:

H6: Customer need tacitness weakens the effects of market exploitation on (a) new product innovativeness and (b) new product development speed.

\section{Research Methods}

\subsection{Sampling Procedure}

The member list of Product Development and Management Association (PDMA) was used as the sampling frame. PDMA is one of the largest innovation organizations worldwide (www.pdma.org). The member list is a representative sample because (a) a majority of members are managers or executives that engage in NPD and they possess adequate knowledge of their firms’ NPD practices (Kahn et al., 2012), and (b) members work in diverse industries and have various functional backgrounds. The PDMA membership is considered as a good representative of the managers and executives in charge of their firms' NPD practices in the United States. A number of past NPD studies have successfully employed this sample frame for research purposes 
(e.g. Calantone \& Di Benedetto, 2007; Markham \& Lee, 2013; Tatikonda \& Montoya-Weiss, 2001).

We employed an online survey to collect data. Because PDMA members were located in diverse geographic areas, the Internet provided fast questionnaire distribution in this national study. The survey design was processed in two stages. First, we drafted a questionnaire and distributed it to 33 NPD practitioners for pre-test. Because of positive feedback and satisfactory reliability $(\alpha>$.70), we made minor changes and then provided a survey link to PDMA, which distributed the link on our behalf to its 2,984 members. The initial distribution was followed by two reminder emails. In total, 341 completed responses were received, which generated an effective response rate of $11.43 \%$. This response rate benchmarked studies that were based on a similar sampling frame (e.g. Calantone \& Di Benedetto, 2007; Kahn et al., 2012; Markham \& Lee, 2013). Because this research required respondents to be actually involved in NPD projects, we removed responses by academic members and practitioners in consulting and financial industries. This step led to 248 remaining responses. Twenty-three cases containing missing values were removed, leaving 225 cases for analysis.

\subsection{Sample Characteristics}

Respondents were practitioners who engaged in NPD practices. Because customer needs and NPD outcomes vary across projects, we considered the NPD project as the unit of analysis. Respondents were asked to focus on one completed NPD project in which they were immediately involved in the past three years. Respondents held management or executive-level positions in their firms, including managers (39.35\%), directors (28.70\%), senior managers (12.50\%), vice president (6.48\%), chief officer (4.17\%), and others (8.80\%). Their functional backgrounds included research and development (R\&D) (36.40\%), project management 
(28.87\%), marketing and sales (27.20\%), manufacturing and operations (2.93\%), and other areas (4.60\%) such as design. Their average work experience was 14.47 years $(\mathrm{SD}=9.76)$ in the current industry and 10.29 years $(\mathrm{SD}=8.96)$ in the current firm. Their average knowledge of the issues addressed in the survey was $5.61(\mathrm{SD}=1.11)$ (1=very limited; 7=very knowledgeable), which exceeded the threshold value of 5 (Li \& Calantone, 1998) and was similar to prior NPD studies (e.g. Kim, Im, \& Slater, 2012; Rindfleisch \& Moorman, 2001).

In addition, the firms were across different industries, including manufacturing (47.95\%), information technology and telecommunication (21.72\%), healthcare (15.57\%), consumer packaged goods (8.61\%), utilities (2.05\%), and others (4.10\%). Their annual sales ranged between below 10 million dollars and over 5 billion dollars. Following Armstrong and Overton (1977), we conducted t-tests to compare key variables of different waves of responses (early vs. late), and found no significant differences between them, suggesting non-response bias is not a significant concern for this study.

\subsection{Measure}

We measured our constructs in the conceptual model with a 7-point scale. The Appendix displays all scale items, factor loadings, and reliability indices. Descriptive statistics and correlation matrix are provided in Table 1.

\section{[Table 1 about here]}

Market Exploration. We adapted the items developed by Kim and Atuahene-Gima (2010), and asked respondents to assess the extent to which their firms used market information or had market activities (a) beyond current product market experiences, (b) led to learning new things, (c) were novel, (d) had potentials to serve future customers, and (e) involved experimentation and high risk. 
Market Exploitation. We adapted the items developed by Kim and Atuahene-Gima (2010), and asked respondents to evaluate the extent to which their firms used market information or had market activities (a) consistent with current product market experiences, (b) to solve existing market problems, (c) to contribute to existing product markets, and (d) to enhance current market experiences.

Customer Need Tacitness. We adapted the items from Ganesan, Malter, and Rindfleisch (2005) to measure customer need tacitness. These items examine the extent to which customer needs can be (a) put, (b) documented, (c) understood, and (d) communicated in the written form.

New Product Innovativeness. We adopted the items from Moorman (1995) for this construct. Respondents were asked to assess the new product in terms of (a) novelty, (b) challenging existing ideas in the industry, (c) offering new ideas to the industry, (d) creativity, (e) interestingness, and (f) new idea generation for other products.

New product development speed. We adopted the items from Rindfleisch and Moorman (2001) to assess the development speed of a new product. Respondents assessed the development speed in the focal project by comparing with (a) original time goals, (b) industry norm, (c) expectation, and (d) typical product development time.

New Product Financial Performance. We adapted measures from existing studies (e.g. Moorman, 1995; Kyriakopoulos \& Moorman, 2004) to assess new product financial performance relative to its stated objectives in terms of (a) return on investment, (b) sales, (c) profit margin, and (d) market share.

We included four control variables in the model. First, other characteristics of customer needs may influence NPD performance. We controlled for the diversity of customer needs and developed scale items based on discussion of De Luca and Atuahene-Gima (2007) and von 
Hippel and Katz (2002). Second, NPD performance in a given project may be affected by the firm’s R\&D investment and organizational activities. We controlled for R\&D intensity and firm size. Firm size was measured in annual sales. Lastly, to control for differences across transactional contexts, we included a dummy variable, BTOC (1=Business-to-Consumer, $0=$ otherwise).

\subsection{Measurement Model, Convergent Validity, and Discriminant Validity}

To assess whether or not constructs were measured appropriately, we used EQS 6.1 to conduct confirmatory factor analysis (Anderson \& Gerbing, 1988). The following fit indices

how satisfactory model fit and unidimensionality (Hu \& Bentler, 1999): $\chi^{2}=724.828$, d.f. $=384$, $p<.001$; Tucker-Lewis index (TLI)=.924; comparative fit index (CFI)=.933; incremental fit index $(I F I)=.934$; standardized root mean square residual $($ SRMR $)=.052$; root mean square error of approximation (RMSEA)=.062. In addition, as the Appendix shows, all reliability indices exceeded .70, all standardized factor loadings exceeded .60, and all average variance extracted (AVE) exceeded .50. Evidence indicates satisfactory reliability and convergent validity of each construct (Fornell \& Larcker, 1981; Nunnally, 1978). As the correlation matrix in Table 1 shows, the square root of a given AVE exceeds correlation coefficients between the pair of corresponding constructs, indicating adequate discriminant validity (Fornell \& Larcker, 1981).

\subsection{Common Method Bias}

We employed two techniques to address the issue of common method bias (Podsakoff et al., 2003). First, Harman's single-factor method was used to test the seven multi-item constructs (shown in the Appendix). We loaded all scale items on one latent variable. The single-factor model showed the following model fit: $\chi^{2}=4127.687$, d.f. $=405, p<.001$; TLI=.215; CFI=.270; IFI $=.274$; SRMR=.186; RMSEA=.199. Compared with the measurement model, the single-factor 
model had a significantly poorer fit $\left(\Delta \chi^{2}=3402.659, \Delta\right.$ d.f. $\left.=21, p<.001\right)$. Second, we conducted exploratory factor analysis including the seven multi-item constructs in the Appendix. Seven factors emerged with eigenvalues greater than 1 , which in total explained $76.83 \%$ of variance. The first factor explained only $24.92 \%$ of variance, suggesting that there was not a dominant factor emerging in the survey instrument. Therefore, we concluded that the common method bias was not a major concern in our study.

\section{Analysis and Results}

\subsection{Model Specification}

Given the nature of the linkages among the three new product outcomes, error terms corresponding to the three equations could be correlated. In this case, seemingly unrelated regression (SUR) constitutes the appropriate estimation approach (Zellner, 1962). SUR takes into account the correlation in errors across equations to yield more efficient regression estimates than an ordinary least squares (OLS) approach (Johnston \& DiNardo, 1997; Zellner, 1962). In the context of this study, some common factors that are not considered by the explanatory variables may influence the errors of different equations in a similar way. For example, a highly uncertain market environment may influence the degree to which a firm is able to achieve these three new product outcomes in a similar way. Also, a pro-innovation bias among our respondents may affect the overall perception of various new product outcomes similarly. Previous research has used SUR in similar models that include equations with new product innovativeness and new product development speed as dependent variables (Fang, 2008). We also examined the possibility of endogeneity in the model but found Hausman test to be insignificant. Thus, two-stage least squares (2SLS) is not appropriate for estimating our model. 
Based on the above reasoning, we tested our hypotheses by estimating a set of SUR models indicated below. Variables were mean-centered before calculating the interaction terms. We followed a stepwise approach to estimate a system of three-equation models.

$$
\begin{aligned}
\text { NPI }= & c_{1}+\beta_{1}(\text { MEXPLOR })+\beta_{2}(\text { MEXPLOT })+\beta_{3}(\text { CTAC })+\beta_{4}(\text { MEXPLOR } \times \text { MEXPLOT })+ \\
& \beta_{5}(\text { MEXPLOR } \times \text { CTAC })+\beta_{6}\left(\text { MEXPLOT } \times \text { CTAC }+\mathrm{CV}+\varepsilon_{1}\right. \\
\text { NPDS }= & c_{2}+\beta_{7}(\text { MEXPLOR })+\beta_{8}(\text { MEXPLOT })+\beta_{9}(\mathrm{CTAC})+\beta_{10}(\text { MEXPLOR } \times \text { MEXPLOT }) \\
& +\beta_{11}(\text { MEXPLOR } \times \text { CTAC })+\beta_{12}(\text { MEXPLOT } \times \text { CTAC })+C V+\varepsilon_{2} \\
\text { NPFP }= & c_{3}+\beta_{13}(\mathrm{NPI})+\beta_{14}(\mathrm{NPDS})+\mathrm{CV}+\varepsilon_{3}
\end{aligned}
$$

where $\mathrm{c}=$ constant, NPI = new product innovativeness, NPDS = new product development speed, NPFP $=$ new product financial performance, MEXPLOR = market exploration, MEXPLOT = market exploitation, $\mathrm{CTAC}=$ customer need tacitness, $\mathrm{CV}=$ control variables, and $\varepsilon=$ error term.

\subsection{Results}

[Table 2 about here]

H1 states that market exploration has a stronger positive effect than market exploitation on new product innovativeness. According to Table 2, market exploration was positively related to new product innovativeness $(\mathrm{b}=.276, p<.001)$, while the effect of market exploitation was not significant ( $p=.627)$. We ran a t-test to compare the two coefficients (Chatterjee \& Hadi, 2006). Results show that the two coefficients were significantly different $(\mathrm{t}=2.258, p<.05)$, supporting H1.

H2 states that market exploitation has a stronger positive effect than market exploration on new product development speed. Table 2 shows that market exploitation was significantly associated with new product development speed $(b=.170, p<.05)$, and the effect of market exploration was marginally significant $(\mathrm{b}=.123, p<.10)$. A t-test shows that the two coefficients were not significantly different ( $\mathrm{t}=.470, p=.639)$. Thus, $\mathrm{H} 2$ is not supported. 
H3 proposes that new product innovativeness and new product development speed mediates the relationships between market exploration/exploitation and new product financial performance. We adopted the procedures recommended by Zhao, Lynch, and Chen (2010) and Hayes (2013) to test the above mediating effects. Since there are two market learning activities and two NPD outcomes, we tested all four potential mediations and found two of them were significant. The mean indirect effect of market exploration on new product financial performance through new product innovativeness was positive and significant $(a \times b=.048$, $\mathrm{SE}=.024 ; 95 \%$ confidence interval $[\mathrm{CI}]=.013, .110$ ), but the direct effect was not significant, as its confidence level included zero ( $\mathrm{c}=.058, \mathrm{SE}=.069 ; 95 \% \mathrm{CI}=-.078, .194)$. The mean indirect effect of market exploitation on new product financial performance via new product development speed was positive and significant $(\mathrm{a} \times \mathrm{b}=.039, \mathrm{SE}=.024 ; 95 \% \mathrm{CI}=.002, .102)$, but the direct effect was not significant ( $c=.135, \mathrm{SE}=.077 ; 95 \% \mathrm{CI}=-.017, .286$ ). Because only the confidence interval of the indirect effects did not contain zero, the results indicate two indirectonly mediations (Zhao, Lynch, \& Chen, 2010). That is, the effect of market exploration on new product financial performance is fully mediated by new product innovativeness while the effect of market exploitation on new product financial performance is fully mediated by new product development speed. H3a and H3b are supported.

$\mathrm{H} 4$ states that the interaction between market exploration and market exploitation has a positive effect on new product innovativeness but a negative effect on new product development speed. As shown in Table 2, the interaction was negatively associated with new product development speed $(\mathrm{b}=-.101, p<.05)$ but not significantly associated with new product innovativeness ( $p=.878)$. Hence, $\mathrm{H} 4 \mathrm{~b}$ is supported but H4a is not supported. 
H5 hypothesizes that customer need tacitness strengthens the effects of market exploration on the two new product outcomes. Table 2 shows that the interaction between customer need tacitness and market exploration was positively associated with both new product innovativeness $(\mathrm{b}=.126, p<.01)$ and new product development speed $(\mathrm{b}=.097, p<.05)$. Thus, H5a and H5b are supported. H6 hypothesizes that customer need tacitness weakens the effects of market exploitation on the two new product outcomes. The results show that the interaction between customer need tacitness and market exploitation was negatively associated with new product innovativeness $(\mathrm{b}=-.113, p<.05)$, but not significantly associated with new product development speed ( $p=.839)$. Thus, H6a is supported but H6b is not supported.

To further understand the three significant moderation effects, we conducted a simple slope analysis following Aiken and West (1991). We set high and low levels of customer need tacitness at one standard deviation above and below the mean (Schmitz, Lee, \& Lilien, 2014). When customer need tacitness is high, market exploration has positive effects on new product innovativeness $(\mathrm{b}=.464, \mathrm{t}=5.018, p<.001)$ and new product development speed $(\mathrm{b}=.270, \mathrm{t}=2.768$, $p<.01$ ), but its effects are not significant when tacitness is low (respectively $\mathrm{t}=.837, p=.404$; $\mathrm{t}=.793, p=.429$ ). Market exploitation has a positive effect on new product innovativeness when customer need tacitness is low ( $\mathrm{b}=.216, \mathrm{t}=1.977, p<.05)$, but its effect is not significant when tacitness is high ( $\mathrm{t}=-1.173, p=.242)$. The graphs are presented in Figure 2.

[Figure 2 about here]

\section{Discussion}

This study examines three distinct ways to balance market exploration and market exploitation in product innovation. First, following the knowledge-based view, we examine whether market exploration and market exploitation can have differential effects on different 
new product outcomes based on their respective learning mechanisms. Our findings suggest that market exploration helps to improve new product innovativeness while market exploitation is more beneficial for new product development speed. Further, these two types of market learning activities can influence new product financial performance via distinct paths. That is, market exploration influences new product financial performance by improving the innovativeness of a product while market exploitation contributes by increasing the speed of NPD. Second, we provide a new piece of empirical evidence on the joint effects of market exploration and market exploitation on new product outcomes, thereby offering new insights into how to achieve an optimal balance between the two types of market learning to gain the desirable innovation outcomes. Third, we examine the contingent role of customer need tacitness and assess whether the innovation outcomes of market exploration and market exploitation differ depending on the level of customer need tacitness. Our findings suggest that market exploration, rather than market exploitation, is more beneficial for improving both new product innovativeness and new product development speed when customer needs are highly tacit. Below we discuss the implications of these findings for both theory and practice.

\subsection{Theoretical Implications}

Despite the growing interests in achieving organizational ambidexterity for a firm's longterm survival, there is no consensus in the existing literature towards how to achieve such balance (e.g. Gupta, Smith, \& Shalley, 2006; Lavie, Kang, \& Rosenkopf, 2011). Our study contributes to the existing literature in the following ways.

First, built upon previous literature on balancing exploration and exploitation within an organization (e.g. Tushman \& O’Reilly, 1996; Raisch et al., 2009), we distinguish between two types of market learning activities, i.e. market exploration and market exploitation, and find that 
these two learning activities have differential effects on new product outcomes based on their different learning mechanisms. In particular, our findings suggest that market exploration facilitates new product innovativeness since the broad search and discovery of new information beyond a firm's current knowledge trajectory can help to create more novel knowledge combinations to better meet customers' changing demands (Atuahene-Gima, 2005; Kogut and Zander, 1992). On the other hand, our findings indicate that market exploitation is beneficial for increasing new product development speed since it helps to improve the efficiency of the NPD process (Kim \& Atuahene-Gima, 2010). Further, our results provide empirical evidence that market exploration and market exploitation can influence new product financial performance through distinct paths. These findings are insightful as they lend empirical support to the premise of organizational ambidexterity, and suggest that firms need to engage in both market exploration and market exploitation in order to ultimately achieve better financial performance of a new product.

Second, this study provides new empirical evidence to resolve the inconsistency in the existing literature regarding the joint effects of market exploration and market exploitation in product innovation. Our findings indicate that simultaneously engaging in high levels of market exploration and market exploitation can reduce new product development speed, and have no significant effect on new product innovativeness. These findings are especially interesting considering the common misconception that a firms needs high levels of both exploration and exploitation in order to achieve better performance (e.g. Raisch \& Birkinshaw, 2008). Our findings suggest that engaging in high levels of both learning activities does not contribute to creating more novel product solutions. Further, a high level of market exploration weakens the positive effect of market exploitation on new product development speed. These findings lend 
support to the idea that firms may need to engage in a "high-low" rather than a "high-high" combination of market exploration and market exploitation in order to achieve a more effective balance between the two (Atuahene-Gima, 2005; Nerkar, 2003). The findings also suggest that achieving organizational ambidexterity is not an easy task since the joint pursuits of market exploration and market exploitation need a delicate balance in order to realize the potential benefits in the NPD process. Rather than simply pursuing a high level of both activities, an organization may benefit from pursuing a high level of market exploration while maintaining a certain level of market exploitation to better leverage its existing competence to create more innovative products. On the other hand, in order to improve new product development speed, a firm may focus on exploiting its existing competence more effectively while keeping a low level of market exploration in order to keeping up with the changes in the dynamic market environment (Atuahene-Gima, 2005; Eisenhardt \& Martin, 2000).

Third, this study examines the contingent role of customer need tacitness in market exploration and market exploitation, which assesses whether the innovation outcomes of such learning differ depending on the level of customer need tacitness. Our findings indicate that market exploration, rather than market exploitation, is more beneficial for both new product innovativeness and new product development speed when customer needs are highly tacit. This finding is particularly insightful given that collecting and sharing customer information within an organization has been found to be critical to improve new product performance (Troy, Hirunyawipada, \& Paswan, 2008). This is also consistent with the previous studies which suggest that market exploration can help to uncover the underlying customer needs and transform the tacit customer knowledge into explicit market information that can be utilized in creating new knowledge combinations (Kogut \& Zander, 1992). Market exploration can also 
help to improve the efficiency of the innovation process and shorten the new product development speed through gaining a better understanding of customer needs and creating a more flexible organizational process to accommodate changes in the market environment (e.g. Eisenhardt \& Martin, 2000). In contrast, our findings suggest that market exploitation seems to undermine new product innovativeness and have no significant effect on new product development speed when customer needs are highly tacit. These findings indicate that market exploitation may not be suitable when firms engage in harnessing highly tacit customer knowledge in the NPD process. Our findings suggest that future research should focus on examining the appropriate organizational configurations and contingency factors that can help firms to minimize the tension between the two learning activities, and realize the full potentials of simultaneously pursuing both activities in the NPD process (e.g. Benner \& Tushman, 2003; March, 1991).

\subsection{Managerial Implications}

Balancing market exploration and market exploitation is an important challenge that companies face. Our study provides a number of ways to better manage such balance in the NPD process. First, firms need to take into account the type of customer knowledge and assess the level of customer need tacitness in order to achieve their desirable innovation outcomes. In particular, when customer needs are highly tacit, firms should emphasize market exploration rather than market exploitation. When a firm faces a high level of customer need tacitness, it is more difficult to obtain valuable market information, thus it needs to take more risks in market learning, such as engaging in more frequent "trial and error" and broader search. In contrast, when there is a low level of customer need tacitness, firms should rely on exploiting their existing market competence. Importantly, the simple slope analysis shows that market 
exploration is only beneficial for new product outcomes when customer needs are highly tacit, whereas market exploitation is only beneficial when tacitness is at a low level. This clear contrast suggests that it is important for firms to carefully align the level of customer need tacitness with their learning strategies, given that market exploration and exploitation often compete for resources.

Second, the balance between market exploration and market exploitation can also be managed by considering the firm's strategic focus in NPD. Our findings indicate that market exploration and market exploitation contribute to new product financial performance via distinct paths: Market exploration improves new product financial performance by enhancing product innovativeness, whereas market exploitation can contribute by increasing product development speed. Thus, when a firm is geared towards developing novel product solutions, more resources should be devoted to exploring new knowledge beyond the current product market domain. On the other hand, when a firm is interested in improving efficiency in the NPD process, it should focus on exploiting the potential of its existing knowledge and skills.

Third, firms also need to consider the joint effects of market exploration and market exploitation in innovation. Pursuing high levels of market exploration and market exploitation simultaneously may reduce new product development speed and potentially hurt new product performance. While it may be necessary to engage in both market exploration and market exploitation, firms should consider a "high-low" rather than a "high-high" combination of the two learning activities in order to avoid potential detrimental impacts. For example, when pursuing a high level of market exploration to improve new product innovativeness, firms need to maintain their existing marketing competence in order to effectively absorb new information. To achieve such balance, firms need to combine market exploration and market exploitation in a 
way that minimizes the tension between these two activities while realizing the potential benefits of the joint pursuit in the NPD process.

\subsection{Limitations and Future Research}

One of the limitations of this study is that results are based on a cross-sectional survey data. To control for this effect, we examined new products launched in the past three-year time frame in order to obtain the performance measures of the new products. A longitudinal study would help to examine the temporal effects of market exploration and market exploitation on NPD performance over time. Future research should consider using a longitudinal technique to provide more support on the temporal value of market learning on different new product outcomes (Nerkar, 2003).

Second, we were not able to obtain objective measures of NPD performance. Although perceptual measures of new product financial performance are commonly used in innovation research (De Luca \& Atuahene-Gima, 2007; Moorman, 1995) and our tests did not show the common method bias, future studies should obtain objective measures of NPD performance to validate the findings of our study.

Third, this study focuses on examining the characteristics of customer information in influencing the balance between market exploration and market exploitation. Since balancing these two learning activities is a challenging and complex task (e.g. Gupta, Smith, \& Shalley, 2006; Lavie, Kang, \& Rosenkopf, 2011), future research should consider other contingency factors such as competitor information and different organizational structures in influencing the above balance.

Fourth, our conceptual model on balancing market exploration and market exploitation was exploratory in nature. It aims to provide a new perspective on how to achieve organizational 
ambidexterity in product innovation. Future research should build upon our study findings and examine other means to achieve such balancing act.

Lastly, while this research focuses on customer knowledge in the market learning process, further research can consider the interplay between market learning and technological learning when studying innovation development. This can help to provide a more comprehensive view towards how to improve overall NPD performance. 


\section{References}

Armstrong, S. J., \& Overton, T. S. (1977). Estimating nonresponse bias in mail surveys. Journal of Marketing Research, 14(3), 396-402.

Adams, M. E., Day, G. S., \& Dougherty D. (1998). Enhancing new product development performance: An organizational learning perspective. Journal of Product Innovation Management, 15(5), 403-422.

Aiken, L. S., \& West, S. G. (1991). Multiple regression: Testing and interpreting interactions. Newbury Park, CA: Sage.

Anderson, J. C., \& Gerbing, D. W. (1988). Structural equation modeling in practice: A review and recommended two-step approach. Psychological Bulletin, 103(3), 411-423.

Atuahene-Gima, K. (2005). Resolving the capability-rigidity paradox in new product innovation. Journal of Marketing, 69(4), 61-83.

product development: A social capital perspective on new technology ventures in China. Journal of International Marketing, 15(2), 1-29.

Benner, M. J., \& Tushman, M. L. (2003). Exploitation, exploration, and process management: The productivity dilemma revisited. Academy of Management Review, 28(2), 238-256.

Birkinshaw, J., Nobel, R., \& Ridderstråle, J. (2002). Knowledge as a contingency variable: Do the characteristics of knowledge predict organization structure? Organization Science, 13(3), 274-289.

Calantone, R. J., \& Di Benedetto, C. A. (2007). Clustering product launches by price launch strategy. Journal of Business \& Industrial Marketing, 22(1), 4-19.

— - _ Harmancioglu, N., \& Droge, C. (2010). Inconclusive innovation "return": A meta-analysis of research on innovation in new product development. Journal of Product Innovation Management, 27(7), 1065-1081.

Cano, C. R., Carrillat, F. A., \& Jaramillo, F. (2004). A meta-analysis of the relationship between market orientation and business performance: Evidence from five continents. International Journal of Research in Marketing, 21(2), 179-200.

Carbonell, P., \& Rodriguez, A. I. (2006). The impact of market characteristics and innovation speed on perceptions of positional advantage and new product performance. International Journal of Research in Marketing, 23(1), 1-12.

Chatterjee, S., \& Hadi, A. S. (2006). Regression analysis by example. Hoboken: John Wiley \& Sons.

Chen, J., Damanpour, F., Reilly, R. R. (2010). Understanding antecedents of new product development speed: A meta-analysis. Journal of Operations Management, 28(1), 17-33.

Cohen, W. M., \& Levinthal, D. A. (1990). Absorptive capacity: A new perspective on learning and innovation. Administrative Science Quarterly, 35(1), 128-152.

Day, G. S. (1994). The capabilities of market-driven organizations. Journal of Marketing, 58(4), 37-52. 
De Luca, L. M., \& Atuahene-Gima, K. (2007). Market knowledge dimensions and crossfunctional collaboration: Examining the different routes to product innovation performance. Journal of Marketing, 71(1), 95-112.

Eisenhardt, K. M., \& Martin, J. A. (2000). Dynamic capabilities: What are they? Strategic Management Journal, 21 (10/11), 1105-1121.

Fang, E. (2008). Customer participation and the trade-off between new product innovativeness and speed to market. Journal of Marketing, 72(4), 90-104.

Fornell, C., \& Larcker, D. F. (1981). Evaluating structural equation models with unobservable variables and measurement error. Journal of Marketing Research, 18(1), 39-50.

Ganesan, S., Malter, A. J., \& Rindfleisch, A. (2005). Does distance still matter? Geographic proximity and new product development. Journal of Marketing, 69(4), 44-60.

Grant, R. M. (1996). Toward a knowledge-based theory of the firm. Strategic Management Journal, 17(Winter), 109-122.

Griffin, A., \& Hauser, J. R. (1996). Integrating R\&D and marketing: A review and analysis of the literature. Journal of Product Innovation Management, 13(3), 191-215.

Gupta, A. K., Smith, K. G., \& Shalley, C. E. (2006). The interplay between exploration and exploitation. Academy of Management Journal, 49(4), 693-706.

Hayes, A. F. (2013). Introduction to Mediation, Moderation, and Conditional Process Analysis: A Regression-Based Approach. New York, NY: Guilford Press.

He, Z. L., \& Wong, P. K. (2004). Exploration vs. exploitation: An empirical test of the ambidexterity hypothesis. Organization Science, 15(4), 481-494.

Henard, D. H. \& Szymanski, D. M. (2001). Why some new products are more successful than others. Journal of Marketing Research, 38(3), 362-375.

Hu, L., \& Bentler, P. M. (1999). Cutoff criteria for fit indexes in covariance structure analysis: conventional criteria versus new alternatives. Structural Equation Modeling, 6(1), 1-55.

Huber, G. P. (1991). Organizational learning: The contributing processes and the literatures. Organization Science, 2(1), 88-115.

Hurley, R. F., \& Hult, G. T. M. (1998). Innovation, market orientation, and organizational learning: An integration and empirical examination. Journal of Marketing, 62(3), 42-54.

Jaworski, B. J., \& Kohli, A. K. (1993). Market orientation: Antecedents and consequences. Journal of Marketing, 57(3), 53-70.

Jehn, K. A., Northcraft, G. B., \& Neale, M. A. (1999). Why differences make a difference: A field study of diversity, conflict, and performance in workgroups. Administrative Science Quarterly, 44(4), 741-763.

Johnston, J. \& DiNardo, J. (1997). Econometric Methods. Burr Ridge, IL: McGraw-Hill.

Kahn, K. B., Barczak, G., Nicholas, J., Ledwith, A., \& Perks, H. (2012). An examination of new product development best practice. Journal of Product Innovation Management, 29(2), 180-192. 
Katila, R., \& Ahuja, G. (2002). Something old, something new: A longitudinal study of search behavior and new product introduction. Academy of Management Journal, 45(6), 11831194.

Kessler, E. H., Bierly, P., \& Gopalakrishnan, S. (2000). Internal vs. external learning in new product development: Effects on speed, costs, and competitive advantage. $R \& D$ Management, 30(3), 213-223.

Kim, N., \& Atuahene-Gima, K. (2010). Using exploratory and exploitative market learning for new product development. Journal of Product Innovation Management, 27(4), 519-536.

— _ - - Im, S., \& Slater, S. F. (2012). Impact of knowledge type and strategic orientation on new product creativity and advantage in high-technology firms. Journal of Product Innovation Management, 30(1), 136-153.

Kogut, B., \& Zander, U. (1992). Knowledge of the firm, combinative capabilities, and the replication of technology. Organization Science, 3(3), 383-397.

Kyriakopoulos, K., \& Moorman, C. (2004). Tradeoffs in marketing exploitation and exploration strategies: The overlooked role of market orientation. International Journal of Research in Marketing, 21(3), 219-240.

Lavie, D., Kang, J., \& Rosenkopf, L. (2011). Balance within and across domains: The performance implications of exploration and exploitation in alliances. Organization Science, 22(6), 1517-1538.

Leonard, D. (2007). Market research in product development. Knowledge creation and management: New challenges for managers, eds. Ichigo, K., \& Nonaka, I. New York: Oxford University Press.

Leonard-Barton, D. (1992). Core capabilities and core rigidities: A paradox in managing new product development. Journal of Marketing, 13(1), 111-125.

Levinthal, D. A., \& March, J. G. (1993). The myopia of learning. Strategic Management Journal, 14(S2), 95-112.

Li, T., \& Calantone, R. J. (1998). The impact of market knowledge competence on new product advantage: Conceptualization and empirical examination. Journal of Marketing, 62(4), 13-29.

Lubatkin, M. H., Simsek, Z., Ling, Y., \& Veiga, J. F. (2006). Ambidexterity and performance in small-to medium-sized firms: The pivotal role of top management team behavioral integration. Journal of Management, 32(5), 646-672.

Madhavan, R., \& Grover, R. (1998). From embedded knowledge to embodied knowledge: New product development as knowledge management. Journal of Marketing, 62(4), 1-12.

March, J. G. (1991). Exploration and exploitation in organizational learning. Organization Science, 2(1), 71-87.

Markham, S. K., \& Lee, H. (2013). Product development and management association's 2012 comparative performance assessment study. Journal of Product Innovation Management, 30(3), 408-429. 
McEvily, S. K., \& Chakravarthy, B. (2002). The persistence of knowledge-based advantage: An empirical test for product performance and technological knowledge. Strategic Management Journal, 23(4), 285-305.

Moorman, C. (1995). Organizational market information processes: Cultural antecedents and new product outcomes. Journal of Marketing Research, 32(3), 318-335.

— - — \& Miner, A. S. (1997). The impact of organizational memory on new product performance and creativity. Journal of Marketing Research, 34(1), 91-106.

Morgan, N. A., Vorhies, D. W., \& Mason, C. H. (2009). Market orientation, marketing capabilities, and firm performance. Strategic Management Journal, 30(8), 909-920.

Nerkar, A. (2003). Old is gold? The value of temporal exploration in the creation of new knowledge. Management Science, 49(2), 211-229.

Nonaka, I. (1994). A dynamic theory of organizational knowledge creation. Organization Science, 5(1), 14-37.

—, —, \& Takeuchi, H. (1995). The knowledge-creating company: How Japanese companies create the dynamics of innovation, New York: Oxford University Press.

Nunnally, J. C. (1978). Psychometric theory. New York: McGraw-Hill.

O’Reilly, C. A., \& Tushman, M. L. (2008). Ambidexterity as a dynamic capability: Resolving the innovator's dilemma. Research in Organizational Behavior, 28, 185-206.

Podsakoff, P. M., MacKenzie, S. B., Lee, J., \& Podsakoff, N. P. (2003). Common method biases in behavioral research: A critical review of the literature and recommended remedies. Journal of Applied Psychology, 88(5), 879-903.

Raisch, S., \& Birkinshaw, J. (2008). Organizational ambidexterity: Antecedents, Outcomes, and Moderators. Journal of Management, 34(3), 375-409.

,,,---- , Probst, G., \& Tushman, M. L. (2009). Organizational ambidexterity: Balancing exploitation and exploration for sustained performance. Organization Science, 20(4), 685-695.

Rindfleisch, A., \& Moorman, C. (2001). The acquisition and utilization of information in new product alliances: A strength-of-ties perspectives. Journal of Marketing, 65(2), 1-18.

Rodríguez-Pinto, J., Carbonell, P., \& Rodríguez-Escudero, A. I. (2011). Speed or quality? How the order of market entry influences the relationship between market orientation and new product performance. International Journal of Research in Marketing, 28(2), 145-154.

Schmitz, C., Lee, Y. C., \& Lilien, G. L. (2014). Cross-selling performance in complex selling contexts: An examination of supervisory- and compensation-based controls. Journal of Marketing, 78(3), 1-19.

Sinkula, J. M. (1994). Market information processing and organizational learning. Journal of Marketing, 58(1), 35-45.

Slater, S. F., \& Narver, J. C. (1995). Market orientation and the learning organization. Journal of Marketing, 59(3), 63-74. 
Sorescu, A. B., \& Spanjol, J. (2008). Innovation's effect on firm value and risk: Insights from consumer packaged goods. Journal of Marketing, 72(2), 114-132.

Tatikonda, M., \& Montoya-Weiss, M. M. (2001). Integrating operations and marketing perspectives of product innovation: The influence of organizational process factors and capabilities on development performance. Management Science, 47(1), 151-172.

Thomke, S. H. (1998). Managing experimentation in the design of new products. Management Science, 44(6), 743-762.

Troy, L. C., Hirunyawipada, T., \& Paswan, A. K. (2008). Cross-functional integration and new product success: An empirical investigation of the findings. Journal of Marketing, 72(6), 132-146.

Tushman, M. L., \& O’Reilly, C. A. (1996). Ambidextrous organizations: Managing evolutionary and revolutionary change. California Management Review, 38(4), 8-30.

von Hippel, E. (1994). "Sticky information" and the locus of problem solving: Implications for innovation. Management Science, 40(4), 429-439.

— , - \& Katz, R. (2002). Shifting innovation to users via toolkits. Management Science, 48(7), 821-833.

Zellner, A. (1962). An efficient method of estimating seemingly unrelated regressions and tests for aggregation bias. Journal of the American Statistical Association, 57(298), 348-368.

Zhao, X., Lynch, J. G., \& Chen, Q. (2010). Reconsidering Baron and Kenny: Myths and truths about mediation analysis. Journal of Consumer Research, 37(2), 197-206.

Zhou, K. Z., \& Wu, F. (2010). Technological capability, strategic flexibility, and product innovation. Strategic Management Journal, 31, 547-561. 
Figure 1. Conceptual Model

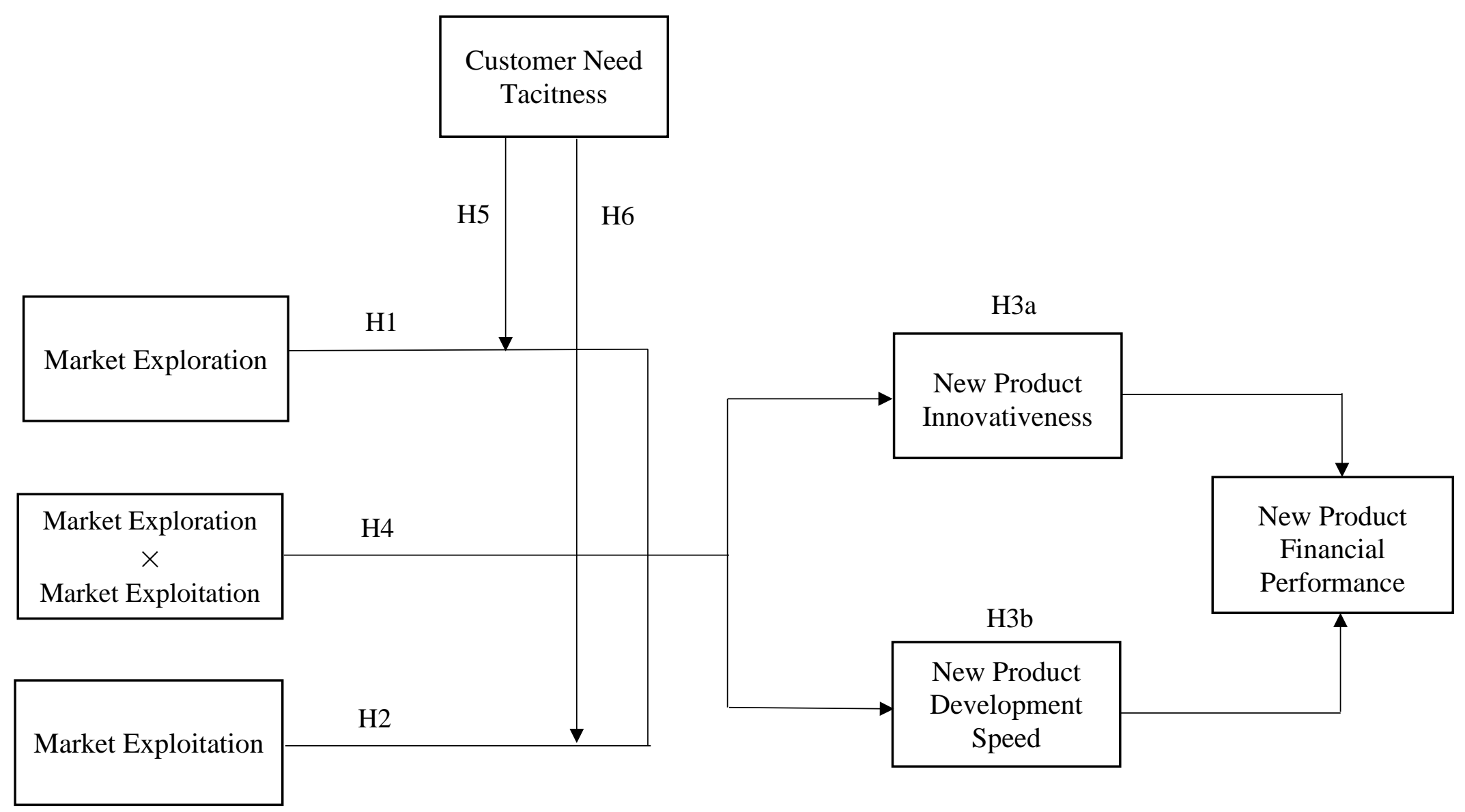


Figure 2. Moderation Effects of Customer Need Tacitness

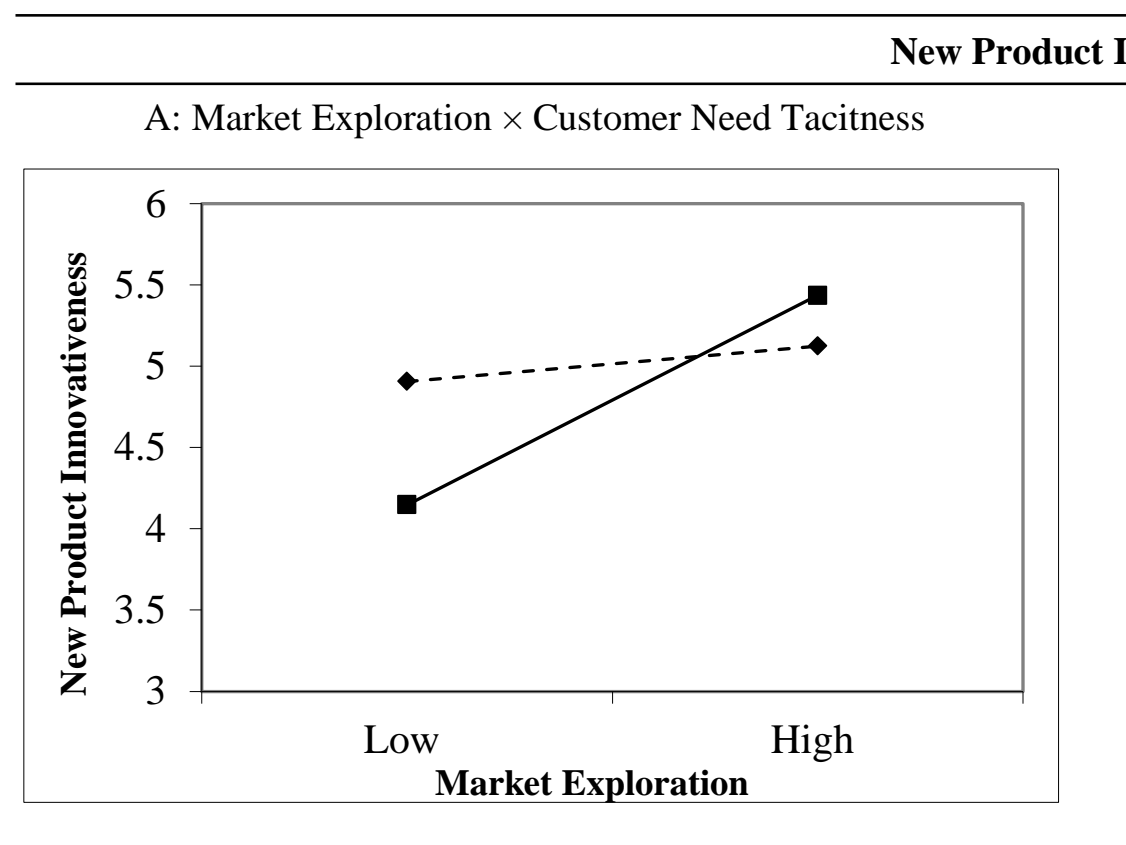

\section{novativeness}

B: Market Exploitation $\times$ Customer Need Tacitness

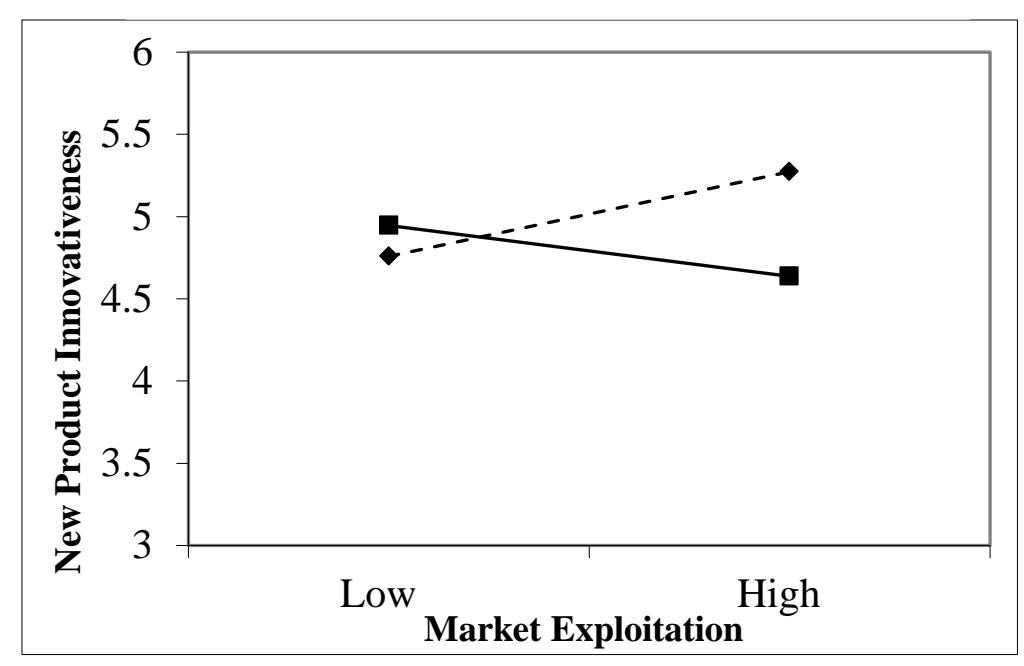

New Product Development Speed

C: Market Exploration $\times$ Customer Need Tacitness

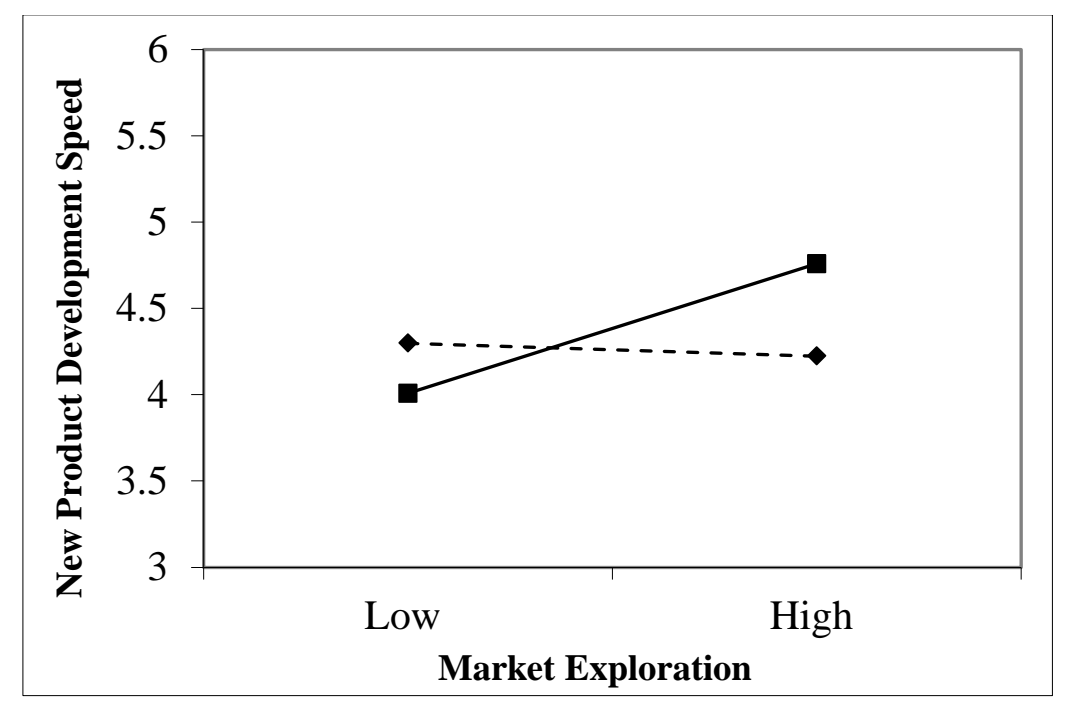

_. . . . . Low Customer Need Tacitnes

— High Customer Need Tacitnes 
Table 1. Descriptive Statistics, Correlations, and Discriminant Validity

\begin{tabular}{|c|c|c|c|c|c|c|c|c|c|c|c|c|}
\hline & Mean & SD & 1 & 2 & 3 & 4 & 5 & 6 & 7 & 8 & 9 & 10 \\
\hline 1. Market Exploration & 4.228 & 1.388 & $(.812)$ & & & & & & & & & \\
\hline 2. Market Exploitation & 4.985 & 1.191 & $.572^{* * *}$ & $(.829)$ & & & & & & & & \\
\hline 3. Customer Need Tacitness & 3.272 & 1.531 & -.002 & -.062 & $(.893)$ & & & & & & & \\
\hline 4. New Product Innovativeness & 4.919 & 1.256 & $.343^{* * *}$ & $.222^{* * *}$ & -.096 & $(.821)$ & & & & & & \\
\hline $\begin{array}{l}\text { 5. New Product Development } \\
\text { Speed }\end{array}$ & 3.751 & 1.241 & $.180^{* *}$ & $.192^{* *}$ & .009 & $.182^{* *}$ & $(.823)$ & & & & & \\
\hline $\begin{array}{l}\text { 6. New Product Financial } \\
\text { Performance }\end{array}$ & 4.394 & 1.228 & $.230^{* * *}$ & $.260^{* * *}$ & .026 & $.295^{* * *}$ & $.337^{* * *}$ & $(.835)$ & & & & \\
\hline 7. Customer Need Diversity & 4.073 & 1.450 & $.210^{* * *}$ & $.120^{\dagger}$ & $.408^{* * *}$ & .069 & .015 & .006 & $(.764)$ & & & \\
\hline 8. R\&D Intensity & 2.530 & 1.189 & $.149^{*}$ & -.008 & .079 & .049 & -.040 & -.089 & .004 & $\mathrm{n} / \mathrm{a}$ & & \\
\hline 9. Firm Size & 4.458 & 1.898 & -.072 & .091 & $-.122^{\dagger}$ & -.088 & -.071 & .009 & -.094 & -.084 & $\mathrm{n} / \mathrm{a}$ & \\
\hline 10. ВTOC & .160 & .370 & .086 & -.002 & .051 & .059 & .006 & .067 & .004 & .070 & -.045 & $\mathrm{n} / \mathrm{a}$ \\
\hline
\end{tabular}

Notes: Diagonal values in parentheses are values of square root of AVEs.

${ }^{\dagger} p<.10,{ }_{p}^{*}<.05,{ }^{* *} p<.01,{ }^{* * *} p<.001$ (two-tailed); $\mathrm{SD}=$ Standard Deviation, $\mathrm{n} / \mathrm{a}=$ Not Applicable 
Table 2. Results of Seemingly Unrelated Regression

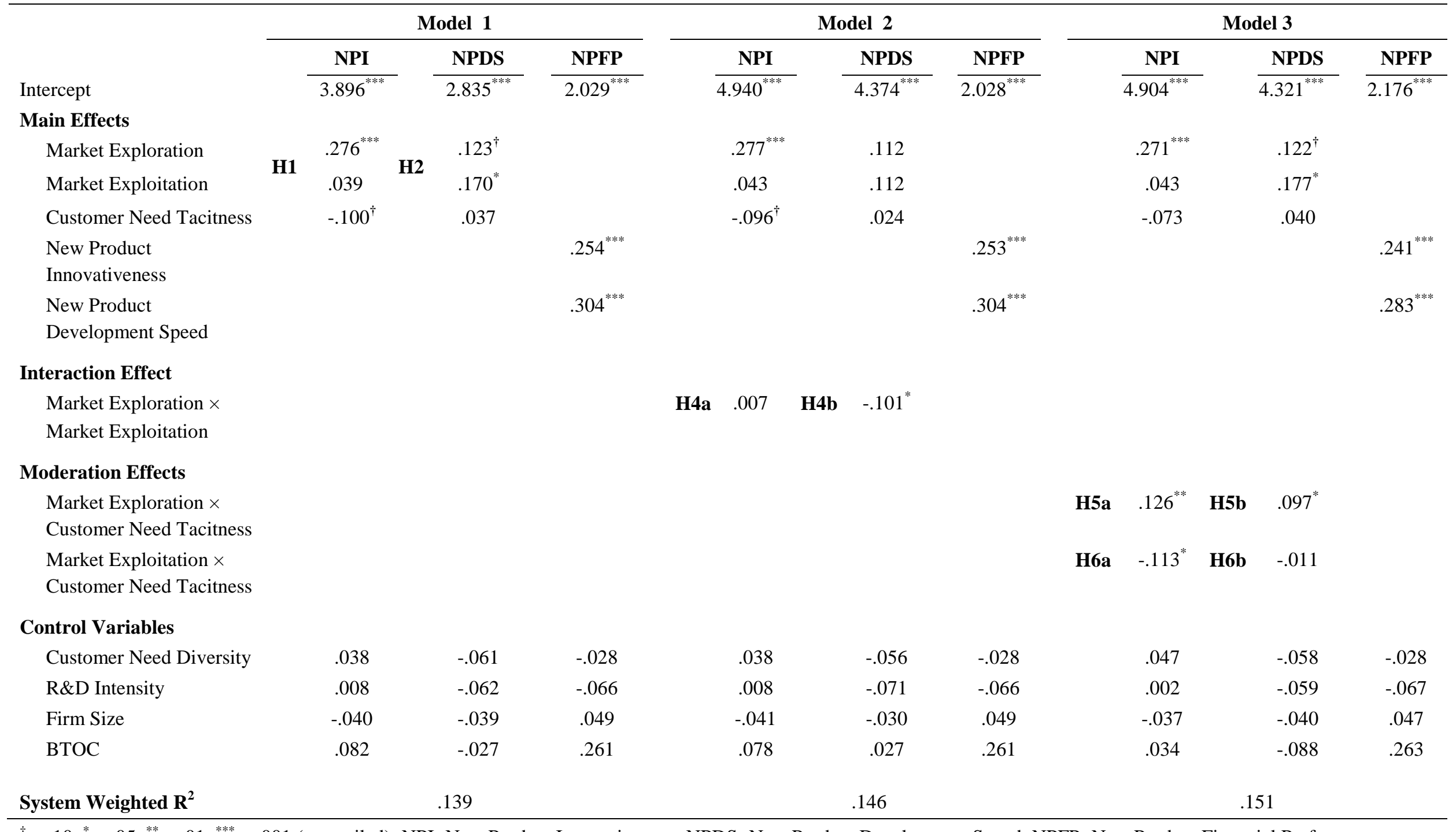

${ }^{\dagger} p<.10,{ }^{*} p<.05,{ }^{* *} p<.01,{ }^{* * *} p<.001$ (two-tailed); NPI=New Product Innovativeness, NPDS=New Product Development Speed, NPFP=New Product Financial Performance 
Appendix. Measure, Confirmatory Factor Analysis and Convergent Validity

Fit Indices for Measurement Model: $\chi^{2}=724.828$, d.f. $=384, p<.001$; TLI=.924; CFI=.933; IFI=.934; SRMR=.052; RMSEA=.062

\begin{tabular}{|c|c|c|c|c|c|}
\hline Construct & Scale Item & SFL & $\alpha$ & CR & AVE \\
\hline Market Exploration & To what extent has your firm... & & .901 & .906 & .659 \\
\hline $\begin{array}{l}\text { (7-point scale; } \\
\text { 1=Very Low, } \\
\text { 7=High) }\end{array}$ & $\begin{array}{l}\text { used market information that takes the firm beyond current product market-experiences } \\
\text { through market experiments? } \\
\text { used market information from leader users that forces the project team members to learn } \\
\text { about new things in your markets? } \\
\text { used novel product/market ideas that may not necessarily be successful in the current } \\
\text { markets? } \\
\text { used market information and ideas that has potential for future customers? } \\
\text { used market information and ideas involving experimentation and high risk? }\end{array}$ & $\begin{array}{l}.782 \\
.832 \\
.781 \\
.882 \\
.778\end{array}$ & & & \\
\hline $\begin{array}{l}\text { Market Exploitation } \\
\text { (7-point scale; } \\
\text { 1=Very Low, 7=Very } \\
\text { High) }\end{array}$ & $\begin{array}{l}\text { To what extent has your firm... } \\
\text { used market information that is consistent with your current product market experiences? } \\
\text { emphasized surveying current customers for solutions to existing market problems? } \\
\text { used market information and ideas that may contribute to the firm's existing product } \\
\text { markets? } \\
\text { undertook activities that help to enhance the firm's current market experiences? }\end{array}$ & $\begin{array}{l}.724 \\
.756 \\
.947 \\
.871\end{array}$ & .889 & .897 & 688 \\
\hline $\begin{array}{l}\text { Customer Need } \\
\text { Tacitness }\end{array}$ & & & .944 & .940 & .798 \\
\hline & Our customers' needs were hard to be put in written form. & .802 & & & \\
\hline $\begin{array}{l}\text { (7-point scale; } \\
\text { 1=Strongly Disagree, } \\
\text { 7=Strongly Agree) }\end{array}$ & $\begin{array}{l}\text { It was difficult to comprehensively document our customers’ needs in written form. } \\
\text { It was difficult to comprehensively understand our customers’ needs form written } \\
\text { documents. }\end{array}$ & $\begin{array}{l}.876 \\
.950\end{array}$ & & & \\
\hline & It was difficult to precisely communicate our customers' needs through written documents. & .938 & & & \\
\hline $\begin{array}{l}\text { New Product } \\
\text { Innovativeness }\end{array}$ & This new product was... & & .924 & .925 & .674 \\
\hline (7-point scale) & Very Ordinary for Our Industry - Very Novel for Our Industry & .813 & & & \\
\hline
\end{tabular}


Not Challenging Existing Ideas in Our Industry - Challenging Existing Ideas in Our

Not Offering New Ideas to Our Industry - Offering New Ideas to Our Industry $\quad .892$

Not Creative - Highly Creative $\quad .870$

Uninteresting - Very Interesting $\quad$ 850

Not Capable of Generating Ideas for Other Products - Very Capable of Generating Ideas .619

New Product

Development Speed

for Other Products

(7-point scale)

The development speed of this new product was...

Slower Than Industry Norm - Faster Than Industry Norm

Much Slower Than We Expected - Much Faster Than We Expected

Lower Than Our Typical Product Development Time - Faster Than Our Typical Product Development Time

\section{New Product}

Financial

Performance

Return on investment relative to its stated objective

(7-point scale; $1=$ Far

Below, 7=Far Above)

Sales relative to its stated objective

Profit margin relative to its stated objective

Market share relative to its stated objective

\section{Control Variables}

\section{Customer Need}

Diversity

(7-point scale; $1=$ Strongly Disagree,

$7=$ Strongly Agree)

Our customers' needs for this project were very diverse.

.755

Our customers' needs could not be fully satisfied with a standardized design.

Our customers had expressed a widely varying set of preferences for the final product $\quad .796$ design.

R\&D Intensity

Approximately what is your company’s R\&D expenditure-to-sales ratio in 2011 or the 
most recent fiscal year?

$<1 \%$; 1-5\%; 6-10\%; 11-15\%; 16-20\%; 21-25\%; >25\%

Firm Size

Approximately what are the total annual sales of your company in 2011 or the most recent fiscal year?

$<10$ million; 10-49 million; 50-99 million; 100-499 million; 500-999 million; 1-5 billion; $>5$ billion

BTOC

1=Primarily Business-to-Consumer; $0=$ otherwise

Notes: All factor loadings are standardized and significant at the .001 level (two-tailed).

SFL=Standardized Factor Loading, $\alpha=$ Cronbach's Alpha, CR=Composite Reliability, AVE=Average Variance Extracted. 